\title{
Evaluating E-Procurement Impact In The Public Sector
}

\author{
Nana Danso Boafo \\ ( nana dd@live.com) Senior Lecturer and Marketing Consultant \\ Eric Ahudey \\ (eadudey@csuc.edu.gh) Lecturer \\ Andrews Ohene Darteh \\ (achenedarteh@gmail.com) Lecturer
}

\begin{abstract}
Despite the several benefits gained as a result of e-procurement, the actual potential of it in the public sector in Ghana has not been realized. Studies has further suggested that little is known of e-procurement in most organizations. This demonstrates that the area is underresearched and hence, there is a gap that needs to be filled in literature on the aspect of e-procurement and its impacts in the public sector in Ghana. Therefore the study was to assess the impact of e-procurement in the Ghanaian public sector. The research design was descriptive. Both primary and secondary data was used. Purposive sample method was used to select 15 public sector organisations in Ghana for the study. Multiple linear regression was used to analyze the data. Findings revealed that, e-procurement leads to an effective E-tender evaluation (ETE), improves transparency in supply selection, improve procurement record management and effective supply relationships can be made easy. Based on the finding the study recommended that, Developing countries governments must invest heavily in eprocurement infrastructure to enable its usage in all sectors. And also procurement officers must also be trained well to enable its usage. And lastly e- procurement should be mandatory in all public sector procurements in the country.
\end{abstract}

Key words: E- procurement, Public sector, Transparency, Developing countries.

\section{INTRODUCTION}

Generally, procurement managers are obliged to comply with all e-procurement regulations (Addison, 2017). This is due to the fact that it affects the purchasing function positively if done effectively. However, scholars have argued that despite the several benefits gained as a result of eprocurement, it seems that the actual potential of it in the public sector has not been realized fully (Chan, He and Wang, 2012). They further suggested that, little is known of e- procurement in most organizations. In recent times, literature suggests that e-procurement has gained interest and attention from both researchers and practitioners. This is due to the fact that firms face the challenge of gaining competitive advantage in the current competitive business environment 
Boafo, N. D., Ahudey, E., \& Darteh, A. O. (2020). Evaluating E-Procurement Impact In The Public Sector. Archives of Business Research, 8(5). 235 -247.

hence, firms need computerization to ensure that they gain as well as sustain their competitive edge over time (Croom and Brandon-Jones, 2007). E-procurement has therefore become the order of the day. This is because e-procurement is a strategic decision that gives a firm a competitive edge in times of economic crisis (Vaidya, Sajeev and Callender, 2006). E-procurement is the process of adopting and integrating the procurement processes and decisions electronically (Aldenius and Khan, 2017).

Authors like Gunasekaran, McGaughey, Ngai and Rai (2009) further emphasized that eprocurement is the current focus of purchasing and supply management. Though, other scholars like Aman and Kasimin (2011) argued that implementing e-procurement is a difficult task for procurement managers particularly, in the public sector. Kotaka (2012) added that e-procurement in the developed economies has received less attention as compared to the attention given to it by developing economies such as Ghana.

In addition, there have been several contributions in the field of procurement management which covers topics like adoption of e-procurement, competitiveness of procurement, definitions of eprocurement (Islam, Murad, McMurray and Abalala, 2017; Toktas-Palut, Baylav, Teoman and Altunbey, 2014; Akibate, 2015). However, little is known in the area of e-procurement and even those works conducted in the area of e-procurement were done in developed economies like Europe, Asia and other developed countries (Croom and Brandon-Jones, 2007; Gunasekaran, McGaughey, Ngai and Rai, 2009). Also, few of such works were done in Sub-Saharan African countries such as Nigeria and Ghana (Eei, Husain and Mustaffa, 2012; Kotoka, 2012). Nonetheless, most of the studies focused on the adoption of e-procurement without looking at the impact of eprocurement. This demonstrates that the area is under-researched and hence, there is a gap that needs to be filled in literature on the aspect of e-procurement and its impacts in the public sector. Therefore, this present study seeks to assess the impact of e-procurement in the Ghanaian public sector.

\section{Procurement}

\section{LITERATURE REVIEW}

According to Weele and Van Raaij (2014), procurement is the processes required to acquire works, goods and services from outside the performing organization. It is favorable that the goods/services are appropriate and that they are procured at the best possible cost to meet the needs of the purchaser in terms of quality and quantity, time, and location. In the view of Software Engineering Institute (2008) at Carnegie Mellon, procurement is a set of activities performed as part of an acquisition effort. It involves process of acquiring goods, works and services, covering both acquisitions from third parties and from in-house providers.

Hui et al. (2011), emphasized that due to the colossal amount of money involved in government procurement and the fact that such money comes from the public, there is need for accountability and transparency therefore, a well-functioning procurement system based on transparency, competition, economy, efficiency and accountability is critical for good economic management and addressing leakages of government funds, improving the effectiveness of public expenditure in poverty reduction and enhancing the public's confidence in government intentions and programmes. Failure to properly manage the procurement process and systems can lead to wasted 
effort and poor development results and consequently increased poverty and deprivation of social and economic rights of the citizenry.

Procurement in this sense, is mainly concerned with acquiring (procuring) all of the goods, works and services that have the optimum importance to the organization. In summary, procurement can be referred to as all the processes involved in the selection, imbursement conditions, hiring and purchasing of goods and services covering both acquisitions from third parties and from in-house providers.

\section{Public Procurement}

Public procurement is a process by which public authority procure to meet the needs and goals of their institutions (Baldi, Bottasso, Conti and Piccardo (2016). Public procurement is crucial to promoting innovation within firms. This is because it helps customers to make informed and wise decisions in the market (Uyarra, Edler, Garcia-Estevez, Gerorghious and Yeow, 2014). They affirmed that public procurement directs its effort to the acquisition of products being it tangible and intangible by both private and public organizations. Also, public procurement aims at achieving accountability and fairness in trade (Spagnolo, 2012).

Mansi (2015), and Mansi and Pandey (2016), advised that public procurement activities enhance corporate social responsibility activities within an organization irrespective of the size of the firm. Despite these known benefits, some scholars like Baldi et al., (2016) concluded in their study that public procurement contributes largely to over-corruption. Notably, public procurement has achieved success in achieving socially responsible goals rather than achieving environmental goals (Amann, Roehrich, EBig and Harland, 2014). Though, the same study suggests that practitioners should enforce public procurement as a means to achieve both environmental and social goals because of the strategic influence public procurement has on such goals.

According to Auriol, Straub and Flochel (2016) public procurement has been the area with a high corruption level in developing economies and Ghana is of no exception. They concluded that the activities of public procurement have risen over the long run. For instance, Statistics show that Paraguay had public procurement operations totaling $6 \%$ of the country's gross domestic product. In the same vein, Torvien and Ulkuniemi (2016) argued that public procurement is influenced by social, economic as well as political events in the business event. Another study like Caloghirou, Protogerous and Panagiotopolous (2016) also claimed that public procurement activities account for $20 \%$ of procurement budget in the European countries but they concluded that findings on public procurement as a driver to innovation remain inconsistent.

According to Witjes and Lozano (2016), Public procurement involves the following stages namely,

1. Stakeholder demand, inventory and selection

2. Definition of product or services

3. Criteria specification

4. Selection of suppliers and signing of the contract

5. Supply of product or service

6. Use of product or service

Essentially, step 1 and 2 refer to the preparation stage; step 3 is known as specification stage; step 4 is the sourcing stage and step 5 and 6 are the utilization stage. Public procurement is observed 
Boafo, N. D., Ahudey, E., \& Darteh, A. O. (2020). Evaluating E-Procurement Impact In The Public Sector. Archives of Business Research, 8(5). 235-247. as an effective strategy that promotes innovation (Edler and Georghiou, 2007) as well as ensuring sustainable supply chain (Bostrom, Jonsson, Lockie, Mol and Oosterveer, 2015).

Again, procurement processes are at the centre of most governmental administration in both developed and developing countries. In the African context, the situation is grave as the procurement procedures seem to face a lot of setbacks. The government of Ghana, in consultation with its development partners, had identified the public procurement system as an area that required urgent attention in view of the widespread perception of corrupt practices and inefficiencies, and to build trust in the procurement system. A study by the World Bank (2003) reported that about $50-70 \%$ of Ghana's National Budget (after personal emoluments) is procurement related.

Therefore, an efficient public procurement system could ensure value for money in government expenditure, which is essential to a country facing enormous developmental challenges.

To ensure sanity and value for money in the public procurement landscape, the government of Ghana in 1996 launched the Public Financial Management Reform Programme (PUFMARP). The exercise was to improve the overall public financial management in the country. The reform exercise identified shortcomings and organizational weaknesses inherent in the country's procurement system. These include the absence of a comprehensive public procurement policy and the lack of a comprehensive legal regime to safeguard the integrity of the public procurement system (World Bank, 2003).

With the introduction of the Public Procurement Law (2003) Act 663, there have been improvements in transparency in the public procurement system in Ghana which contribute to a more efficient allocation of resources through increased competition, and higher quality procurement. Transparency in the public procurement systems in Ghana has also helped in attracting more investment. Additionally, objective and transparent procedures in the public procurement systems enhanced the efficiency of local suppliers and contractors as they compete for public contracts. There is an improvement in tax payments, expanded private sector, with some foreign companies going into joint venture with Ghanaian businesses, generating employment and prospects for the economy. Finally, in the view of Organization Economic Cooperation Development (2003), transparent procurement procedures helped limit bribery and corruption, which are particularly rampant in the procurement field in both developed and developing countries.

The procurement Act 663 deals with purchasing and the main objectives of Act 663 are to harmonize public procurement processes in the public service, is to secure judicious, economic and efficient use of state resources and to ensure that public procurement functions undertaken within the public sector are fair, transparent and non-discriminatory. The Act makes reference to procurements financed wholly or partly from public funds; with respect of procurement of goods, works, services and contract administration. Reference is also made to disposal of public stores and equipment and procurements financed by funds or loans taken by the government of Ghana, including foreign aid funds. Act 663 however, has some exceptions and does not apply to some situations such as:

- Where the Minister decides that alternative procedures are in the national interest and 
- Where a loan or funding agreement specifies alternative procedures and excludes stores management and distribution (Public Procurement Act, 2003 (Act 663)).

Interestingly, the act has established limits on thresholds on how much to procure. The Public Procurement Act (Act 663) in Ghana tends to expand reforms covering procurement and project delivery strategies and methods with a focus on best value intended to maximize the potential and likelihood of achieving value for money in public procurement in Ghana. With improved public financial management due to transparency and accountability in public procurement as a result of procurement reforms, the World Bank (2003) and Anvuur et al., (2006) envisaged that there will be an annual savings of about US $\$ 150$ million in government-financed procurement alone in Ghana.

\section{Supply Chain and E-Procurement}

E-Procurement refers to the use of an internet-based system used to carry out individual or all stages of procurement processes, including search, sourcing, negotiation, ordering, receipt, and post-purchase review (Croom and Brandon, 2004). E-procurement is defined by Loughlin (2010) as the business-to-business purchase and sale of supplies and services over the Internet. He further explained; e-procurement is sometimes referred to as supplier exchange. Typically, e-procurement web sites allow qualified and registered users to look for buyers or sellers of goods and services. Koorn et al (2001) describe three types of e-Procurement systems which are buyer e-Procurement systems; seller e-Procurement systems; and online intermediaries.

There are various forms of e-procurement that concentrate on one or many stages of the procurement process, such as e-tendering, e-marketplace, auction/ reverse auction, and ecatalogue. The e- Procurement application can be viewed more broadly as an end-to-end solution that integrates and streamlines many procurement processes throughout the organization. Introduction of any system must have its objectives that the firm wishes to achieve. The main objectives of e-Procurement are: to reduce the time and cost of doing business for both vendors and the purchasers; to realize better value for money spent through increased competition; to standardize the procurement processes across departments/agencies and to allow equal opportunity all vendors and to bring transparency in the supply chain.

In recent times, many research works have focused on the implementing of e-procurement solutions to enhance effective and efficient purchasing in organizations. It is of much essence to state that e-procurement has changed the way businesses purchase goods and services in that most products are procured using electronic data interchange and the internet. Also, the use of eprocurement cut across both manufacturing and services industry.

\section{The Impacts of E-Procurement in an Organization}

\section{Empirical Study of Impact of E-Procurement on an Organization}

Capen, et al (1971) conducted a study on the effects of effective e-procurement on firms. From their study, it came out that, e-procurement helps in decision-making process by keeping relevant information neatly organized and time-stamped. Most are template-driven which makes all transactions standardized. Keeping track of all bids means leveraging your knowledge to obtain better pricing. Companies can focus on their most lucrative trading partners and contracts. Well managed e-procurement helps reduce inventory level, increase efficiency and cost savings (faster 
Boafo, N. D., Ahudey, E., \& Darteh, A. O. (2020). Evaluating E-Procurement Impact In The Public Sector. Archives of Business Research, 8(5). 235-247. and cheaper) in government procurement and improves transparency (to reduce corruption) in procurement services. Knowing product numbers, bid prices and contact points can help businesses close a deal while other suppliers are struggling to gather their relevant data. EProcurement systems that allow multiple access levels and permissions help managers organize administrative users by roles, groups, or tasks. Procurement managers do not need to be as highly trained or paid because such systems are standardized and easy to learn. Empirical studies carried out by Gebauer et al (1988) in the United States of America indicated that the two most important measures for the success of procurement processes are cost and time. In this method, there is no paperwork, postage fee and other costs associated with preparation and sending tender documents. In their study, it was as well seen that, e-procurement activities is faster to send a document electronically as compared to the traditional method of sending tender documents through the post office. It results in improved order tracking and tracing, for it is much easier to trace the orders and make necessary corrections in case an error is observed in the previous order. Secondly, there is reduction in time to source materials: Reduction in time has been proved as a relevant benefit by Witting, (2003), a study conducted to find out the benefits of technology in procurement. From the study, -E-procurement was seen to be a rapid efficient method of finding and connecting new sources, being a lean channel for communication\|. A lot of time is spent on paper invoicing in terms of writing, filing and postal communication but while in e-procurement, staff have sufficient time to engage in strategic issues of procurement the time wasted in moving from one town or country to another to look for a potential supplier or buyer is greatly reduced since with a click of a button, you can readily get the information in the internet. By extension, Eprocurement leads to reduction in maverick buying. Maverick buying is when staff buys from suppliers than those with whom a purchasing agreement has been negotiated. A study conducted by Puschmann (2005) in the UK on Electronic Procurement Management argued that, Eprocurement lowers administration costs: in his research, he stated that e procurement results in reduction in paperwork and this leads to lower administration costs.

Loughlin (2010) stated in his study that, technology in procurement helps in the reduction in procurement staff. Since much of the procurement process is done electronically, the number of staff needed to facilitate the process reduces. As noted in his study, the reduction in staff is an important way of producing competitive advantage through reduced costs. This is further supported by Lee et al (2000) in their study which revealed that through implementation of an eprocurement system, a steel supplier was able to carry out a multi-million-pound project with only $20 \%$ of the staff the company would normally have used. Koorn et al, (2001) stated in their study on impact of e-procurement activities in the manufacturing company. They found out that, eprocurement gives an organization competitive advantage over its competitors. As a centralized department can oversee all procurement activities and different offices worldwide can access the same documentation when required, this gives a distinct advantage over the much slower process of having to post documentation between offices. This extends the supply chain beyond geographical boundaries to a much wider group. Suppliers can be monitored on timely delivery, quality delivery of products and services hence performing suppliers can be contacted in future. This raises other logistical considerations which may impact on scheme quality (Koorn et al, 2001). This implies that with e-procurement, every prospective supplier and buyer is always accessible to his/her convenience. The result is not only greater market access but also increased productivity. Another benefit of e-procurement is improvement of communication as defined clearly by Koorn et al (2001). They stated categorically in their study that, eprocurement allows 
sections of electronic documentation to flow through the supply chain; it improves the speed of returns and subcontractor price visibility. They further noted that since it is easier to communicate requirements in a quicker more accessible manner, it will result in a better understanding of requirements and due compliance besides allowing clients to gauge the state of the market by seeing how much interest is shown in the tender. Birks et al, (2001) considered market intelligence and the decisions made on that intelligence as two separate drivers. They however state that since reliable procurement decisions cannot be made without market intelligence and each is reliant on the other for the purpose of this study these two are considered together as -Improved Market Intelligence and Enhanced Decision making\|. A reduced Operating and Inventory cost is also another benefit of e-procurement: This is from the fact that much if not all paperwork is eliminated. Postage costs are also not incurred, among other expenses associated with sending and receiving documents when sending them by post.

Empirical evidence supports the fact that e-procurement impacts on the activities of an organization. Gunasekaran and Ngai (2008) concluded in their study that e-procurement makes purchasing activities more effective in terms of time and cost hence, it has changed the way businesses are conducted in terms of purchasing of goods. Other scholars like Sanders (2007) affirms that procurement impacts on performance both directly and indirectly. Quesada, Gonzalez, Muller and Mueller (2010) added that e-procurement improves procurement performance significantly. This indicates that e-procurement is of significance to the organization in that it affects their operations directly or indirectly.

Others stated that e-procurement promotes cost savings and increased effectiveness in an organization despite the size of the firm (Gunasekaran et al., 2009). Cost savings in procurement over time is very crucial to the firm and arguments made by several studies conducted in the area of e-procurement conclude that e-procurement indeed contributes to cost savings or efficiency in transaction and competitive sourcing opportunities (Subramaniam and Shaw, 2014; Angeles and Nath, 2007; Croom and Brandon-Jones, 2005; Croom and Brandon-Jones, 2007).

Additionally, one of the important impacts of e-procurement is its ability to share integrated information and its efficient use of information technology in an organization which aids productivity (Toktas-Pault, Baylav, Teoman, Altubey, 2014; Carayannis and Popescu, 2005). This provides a transparent and efficient means of procuring goods and services in an organization.

\section{RESEARCH METHODOLOGY}

The research design was descriptive. Both primary and secondary data was used. The nature of secondary data used was existing literature such as journals articles, research papers, books and magazines. The study population was the public sector organisations in Ghana. Purposive sample method was used to select 15 public sector organisations in Ghana for the study. The adoption of purposive sampling method for the study was informed by the need to obtain key and relevant information that could meet the objective of the study. Multiple linear regression was used to analyze data. 
ANALYSIS OF DATA AND DISCUSSIONS

\section{The Impacts of E-Procurement Implementation in the Public Sector}

In assessing the impacts of e-procurement implementation in the Ghanaian public sector, data collected were analyzed using both and regression and correlation.

\section{Regression analysis of the impacts of E-procurement implementation in the Ghanaian public sector. \\ E-tendering (ET)}

The study assessed E-tendering (ET) in relation to e-procurement implementation in the public sector and from Table 4, the results indicate that there is a direct relationship between the Etendering (ET) and e-procurement implementation. The Beta coefficient of 2.481 and t-value of 2.641 and $P$ value of 0.000 . This shows a positive coefficient and a statistically significant result of e-tendering related with e-procurement implementation and its effectiveness. This reveals that eprocurement makes E-tendering more transparent and timely, hence, improving the means of procuring goods and services.

\section{E-supplier relationship management (ESRM)}

The result shows that there was a direct or positive relationship between E-supplier relationship management (ESRM) and the effectiveness of e-procurement implementation. The $\beta$ coefficient of 1.655 and a t-value of 1.864 at a significance level of 0.000 . This is positively related to eprocurement implementation. This reveals that e-procurement supports E-supplier relationship management (ESRM) which ensures that supplier relationship has improved and exchange of information is timely and accurate.

\section{E-requisition (ER)}

Analysis of ER has a $\beta=0.802$ and a t-value of 1.784 at a significance level of 0.000 . This indicates that E-requisition (ER) was positively related with the effectiveness of e-procurement. This shows that e-procurement promotes E-requisition which ensures that there is accurate and transparent means to make requisitions.

\section{E-tender evaluation (ETE)}

The results from table 4, shows that ETE has a $\beta=1.283$ and a t-value of 2.772 and it is statistically significant at 0.000. This shows that e-procurement leads to an effective E-tender evaluation (ETE) which helps to carry out evaluation in a more timely and transparent manner and hence, there is a positive relationship between e-procurement and E-tender evaluation (ETE).

\section{E-supplier selection (ESS)}

From table 4, E-supplier selection (ESS) has a $\beta=1.341$ and t-value of 2.470 at a significance level of 0.000. This indicates that there is a positive relationship between EPI and ESS and this demonstrates that e-procurement implementation leads to effectiveE-supplier selection (ESS). This means supplier selection is more transparent and suppliers are given equal opportunities. 
Table 1. Regression analysis of the impacts of E-procurement implementation in the Ghanaian public sector

\begin{tabular}{|c|c|c|c|c|c|}
\hline \multirow{2}{*}{ Ro=0.841 } & \multicolumn{2}{c}{$\mathbf{R}^{\mathbf{2}}=\mathbf{0 . 6 5 0}$} & $\mathbf{F}=\mathbf{1 3 . 7 1 2}$ Std. Error of the Estimate= 3.821 & \multicolumn{2}{c|}{ P=.000 } \\
\hline & \multicolumn{2}{|c|}{ Unstandardized Coefficients } & $\begin{array}{c}\text { Standardized } \\
\text { Coefficients }\end{array}$ & \multirow{2}{*}{$\mathrm{T}$} & \multirow{2}{*}{ Sig. } \\
\cline { 2 - 6 } & $\mathrm{B}$ & Std. Error & Beta & & \\
\hline (Constant) & 3.758 & .765 & & 4.914 & .000 \\
\hline ET & 2.481 & .182 & 629 & 2.641 & $.000^{* *}$ \\
\hline ESRM & 1.655 & .351 & .443 & 1.864 & $.000^{* *}$ \\
\hline ER & .802 & .450 & .444 & 1.784 & $.000^{* *}$ \\
\hline ETE & 1.283 & .463 & .710 & 2.772 & $.000^{* *}$ \\
\hline ESS & 1.341 & .543 & .742 & 2.470 & $.000^{* *}$ \\
\hline EPRM & 4.214 & .350 & .300 & 3.875 & $.000^{* *}$ \\
\hline
\end{tabular}

$* * \mathrm{P}<0.01,95 \%$ level of confidence, $N=30$

Source: Field Survey, 2019

From the table 1, it can be realized that the model summary indicates a level of significance and this is shown by the F-Statistic value of 13.712 and a P value of 0.000 . This clearly demonstrates a stronger relationship between the independent and dependent variables used in the regression analysis; in that there is a best fit of the model to predict the implementation of e-procurement in the public sector. The beta coefficient also shows both the positive and negative effect of independent variables on the dependent variable and from the table 1, it was observed that the beta coefficient indicates a positive effect in predicting the dependent variable. This portrays that any increase in the independent variables lead to an increase in the dependent variable thus eprocurement implementation (EPI).

\section{Correlation Analysis}

Table 2: Correlation Matrix

\begin{tabular}{|c|c|c|c|c|c|c|c|}
\hline Variables & EPI & ET & ESRM & ER & ETE & ESS & EPRM \\
\hline $\begin{array}{c}\text { E-procurement } \\
\text { Implementation }\end{array}$ & 1 & $.413^{* *}$ & 1 & & & & \\
\hline E-tendering (ET) & $.347^{* *}$ & $.453^{* *}$ & 1 & & & \\
\hline $\begin{array}{c}\text { E-supplier } \\
\text { relationship } \\
\text { management } \\
\text { (ESRM) }\end{array}$ & $.478^{* *}$ & $.562^{* *}$ & .310 & 1 & & 1 & \\
\hline E-requisition(ER) & $.696^{* *}$ & $.597^{* *}$ & $.474^{* *}$ & $.361^{*}$ & .108 & .264 & 1 \\
\hline $\begin{array}{c}\text { E-tender } \\
\text { evaluation (ETE) }\end{array}$ & $.520^{* *}$ & $.411^{* *}$ & .283 & .2867 & .273 \\
\hline $\begin{array}{c}\text { E-supplier } \\
\text { selection (ESS) }\end{array}$ & $.411^{* *}$ & $.350^{* *}$ & .215 & .286 & 1 \\
\hline $\begin{array}{c}\text { E-procurement } \\
\text { records } \\
\text { management } \\
\text { (EPRM) }\end{array}$ & & & & & 1 \\
\hline
\end{tabular}

** Correlation is significant at 0.01 level (1-tailed) * correlation is significant at 0.05 level (1-tailed) Source: Field Survey, 2019 
Boafo, N. D., Ahudey, E., \& Darteh, A. O. (2020). Evaluating E-Procurement Impact In The Public Sector. Archives of Business Research, 8(5). 235 -247.

Table 2 describes the correlation between the independent variables and the dependent variables. It can be further observed that there are some significant findings. It is also important to note that ET, ESRM, ER, ETE, ESS and EPRM are the independent variables whereas EPI is the dependent variable. Again, the results show that there are strong correlations between the dependent variable thus e-procurement implementation (EPI) and independent variables; ET ( $\mathrm{r}=0.413)$, ESRM ( $\mathrm{r}=$ 0.347), ER $(\mathrm{R}=478)$, ETE $(\mathrm{r}=0.696)$, ESS $(\mathrm{r}=0.520)$ AND EPRM $(\mathrm{R}=0.411)$ with $(\mathrm{P}<0.01)$ respectively.

This demonstrates that there is a positive relationship between e-procurement and all the independent variables used. From the data analysis, it is clear that there is a positive relationship between EPI and the independent variables at a significance level of 5\%. This shows that all the 6 of the independent variables namely, ET, ESRM, ER, ETE, ESS and EPRM were statistically significant and are the main determinants of e-procurement implementation.

\section{RECOMMENDATIONS AND CONCLUSIONS}

The e- Procurement application can be viewed more broadly as an end-to-end solution that integrates and streamlines many procurement processes throughout the organization. An efficient public procurement system could ensure value for money in government expenditure, which is essential to a country facing enormous developmental challenges.

Based on these findings of the study the researcher recommends that,

1. Developing countries governments must invest heavily in e-procurement infrastructure to enable its usage in all sectors.

2. Procurement officers must also be trained well to enable its usage.

3. E- Procurement should be mandatory in all public sector procurements in the country.

\section{References}

Addison, D., 2017. Implementation and adoption of E-Procurement in Ghana Public Sector: the way forward (Doctoral dissertation).

Akibate, P.P., 2015. The Acceptance of E-Procurement in Ghana: A Study of Key Stakeholders in the Construction Industry in Greater Accra (Doctoral dissertation).

Altayyar, A. and Beaumont-Kerridge, J., 2016. External Factors Affecting the Adoption of E-procurement in Saudi Arabian's SMEs. Procedia-Social and Behavioral Sciences, 229, pp.363-375.

Altayyar, A. and Beaumont-Kerridge, J., 2016. External Factors Affecting the Adoption of E-procurement in Saudi Arabian's SMEs. Procedia-Social and Behavioral Sciences, 229, pp.363-375.

Aman, A. and Kasimin, H., 2011. E-procurement implementation: a case of Malaysia government. Transforming Government: People, Process and Policy, 5(4), pp.330-344.

Aman, A. and Kasimin, H., 2011. E-procurement implementation: a case of Malaysia government. Transforming Government: People, Process and Policy, 5(4), pp.330-344.

Aman, A. and Kasimin, H., 2011. E-procurement implementation: a case of Malaysia government. Transforming Government: People, Process and Policy, 5(4), pp.330-344.

Amann, M., K. Roehrich, J., Eßig, M. and Harland, C., 2014. Driving sustainable supply chain management in the public sector: The importance of public procurement in the European Union. Supply Chain Management: An International Journal, 19(3), pp.351-366.

Angeles, R. and Nath, R., 2007. Business-to-business e-procurement: success factors and challenges to implementation. Supply Chain Management: An International Journal, 12(2), pp.104-115. 
Auriol, E., Straub, S. and Flochel, T., 2016. Public procurement and rent-seeking: the case of Paraguay. World Development, 77, pp.395-407.

Azanlerigu, J.A. and Akay, E., 2015. Prospects and challenges of e-procurement in some selected public institutions in Ghana. Prospects, 7(29).

Baldi, S., Bottasso, A., Conti, M. and Piccardo, C., 2016. To bid or not to bid: That is the question: Public procurement, project complexity and corruption. European Journal of Political Economy, 43, pp.89-106.

Boström, M., Jönsson, A.M., Lockie, S., Mol, A.P. and Oosterveer, P., 2015. Sustainable and responsible supply chain governance: challenges and opportunities. Journal of Cleaner Production, 107, pp.1-7.

Brandon-Jones, A. and Carey, S., 2011. The impact of user-perceived e-procurement quality on system and contract compliance. International Journal of Operations \& Production Management, 31(3), pp.274-296.

Carayannis, E.G. and Popescu, D., 2005. Profiling a methodology for economic growth and convergence: learning from the EU e-procurement experience for central and eastern European countries. Technovation, 25(1), pp.1-14.

Croom, S. and Brandon-Jones, A., 2007. Impact of e-procurement: experiences from implementation in the UK public sector. Journal of Purchasing and Supply Management, 13(4), pp.294-303.

Croom, S. and Brandon-Jones, A., 2007. Impact of e-procurement: Experiences from implementation in the UK public sector. Journal of Purchasing and Supply Management, 13(4), pp.294-303.

Croom, S.R. and Brandon-Jones, A., 2005. Key issues in e-procurement: procurement implementation and operation in the public sector. Journal of Public Procurement, 5(3), pp.367-387.

Di Pietro, L., Mugion, R.G., Mattia, G., Renzi, M.F. and Toni, M., 2015. The integrated model on mobile payment acceptance (IMMPA): an empirical application to public transport. Transportation Research Part C: Emerging Technologies, 56, pp.463-479.

Edler, J. and Georghiou, L., 2007. Public procurement and innovation-Resurrecting the demand side. Research policy, 36(7), pp.949-963.

Eei, K.S., Husain, W. and Mustaffa, N., 2012. Survey on benefits and barriers of e-procurement: Malaysian SMEs perspective. International Journal on Advanced Science, Engineering and Information Technology, 2(6), pp.424-429.

Gunasekaran, A. and Ngai, E.W., 2008. Adoption of e-procurement in Hong Kong: An empirical research. International Journal of Production Economics, 113(1), pp.159-175.

Gunasekaran, A., McGaughey, R.E., Ngai, E.W. and Rai, B.K., 2009. E-Procurement adoption in the Southcoast SMEs. International Journal of Production Economics, 122(1), pp.161-175.

Gunasekaran, A., McGaughey, R.E., Ngai, E.W. and Rai, B.K., 2009. E-Procurement adoption in the Southcoast SMEs. International Journal of Production Economics, 122(1), pp.161-175.

Hallikainen, H. and Laukkanen, T., 2016, June. How technology readiness explains acceptance and satisfaction of digital services in B2b healthcare sector?. In PACIS (p. 294).

Hanafizadeh, P., Behboudi, M., Koshksaray, A.A. and Tabar, M.J.S., 2014. Mobile-banking adoption by Iranian bank clients. Telematics and Informatics, 31(1), pp.62-78.

Kabir, M.R., 2013. Factors influencing the usage of mobile banking: Incident from a developing country. World Review of Business Research, 3(3), pp.96-114.

Kasemsap, K., 2017. Strategic innovation management: An integrative framework and causal model of knowledge management, strategic orientation, organizational innovation, and organizational performance. In Organizational Culture and Behavior: Concepts, Methodologies, Tools, and Applications (pp. 86-101). IGI Global.

Kithinji, L.W., 2014. Internet marketing and Performance of Small and medium Enterprises in Nairobi County. University of Nairobi.

Kotoka, F.A., 2012. Assessing the level of Compliance with the Public Procurement Act 2003 (Act 663) in Public Entities in Ashanti Region of Ghana. Unpublished Commonwealth Executive Masters in Public Administration thesis, Kwame Nkrumah University of Science and Technology. 
Boafo, N. D., Ahudey, E., \& Darteh, A. O. (2020). Evaluating E-Procurement Impact In The Public Sector. Archives of Business Research, 8(5). 235 -247. Lee, Y.K., Park, J.H., Chung, N. and Blakeney, A., 2012. A unified perspective on the factors influencing usage intention toward mobile financial services. Journal of Business Research, 65(11), pp.1590-1599.

Lu, Y., Yang, S., Chau, P.Y. and Cao, Y., 2011. Dynamics between the trust transfer process and intention to use mobile payment services: A cross-environment perspective. Information \& Management, 48(8), pp.393-403.

Mallat, N., Rossi, M., Tuunainen, V.K. and Öörni, A., 2009. The impact of use context on mobile services acceptance: The case of mobile ticketing. Information \& management, 46(3), pp.190-195.

Mansi, M. and Pandey, R., 2016. Impact of demographic characteristics of procurement professionals on sustainable procurement practices: Evidence from Australia. Journal of Purchasing and Supply Management, 22(1), pp.31-40.

Mansi, M., 2015. Sustainable procurement disclosure practices in central public sector enterprises: evidence from India. Journal of Purchasing and Supply Management, 21(2), pp.125-137.

Maradung, P., 2013. Factors affecting the adoption of mobile money services in the banking and financial industries of Botswana (Doctoral dissertation).

Matt, D.T., Rauch, E. and Franzellin, V.M., 2014. An axiomatic design-based approach for the patient-value-oriented design of a sustainable Lean healthcare system. International Journal of Procurement Management, 8(1-2), pp.66-81.

Mothobi, O. and Grzybowski, L., 2017. Infrastructure deficiencies and adoption of mobile money in Sub-Saharan Africa. Information Economics and Policy, 40, pp.71-79.

Ouma, S.A., Odongo, T.M. and Were, M., 2017. Mobile financial services and financial inclusion: Is it a boon for savings mobilization?.Review of development finance, 7(1), pp.29-35.

PresuttiJr, W.D., 2003. Supply management and e-procurement: creating value added in the supply chain. Industrial marketing management, 32(3), pp.219-226.

Quesada, G., González, M.E., Mueller, J. and Mueller, R., 2010. Impact of e-procurement on procurement practices and performance. Benchmarking: An International Journal, 17(4), pp.516-538.

Ronchi, S., Brun, A., Golini, R. and Fan, X., 2010. What is the value of an IT e-procurement system?.Journal of Purchasing and Supply management, 16(2), pp.131-140.

Sanders, N.R., 2007. An empirical study of the impact of e-business technologies on organizational collaboration and performance. Journal of Operations Management, 25(6), pp.1332-1347.

ShuHui, W., Othman, R., Hj Omar, N., Abdul Rahman, R. and HusnaHaron, N., 2011. Procurement issues in Malaysia. International journal of public sector Management, 24(6), pp.567-593.

Smart, A., 2010. Exploring the business case for e-procurement. International Journal of Physical Distribution \& Logistics Management, 40(3), pp.181-201.

Spagnolo, G., 2012. Reputation, competition, and entry in procurement. International Journal of Industrial Organization, 30(3), pp.291-296.

Tanner, C., Wölfle, R., Schubert, P. and Quade, M., 2008. Current trends and challenges in electronic procurement: an empirical study. Electronic Markets, 18(1), pp.6-18.

Telgen, J., 1998. Revolution through electronic purchasing. BETA, Institute for Business Engineering and Technology Application.

Teo, T.S., Lin, S. and Lai, K.H., 2009. Adopters and non-adopters of e-procurement in Singapore: An empirical study. Omega, 37(5), pp.972-987.

Toktaş-Palut, P., Baylav, E., Teoman, S. and Altunbey, M., 2014. The impact of barriers and benefits of e-procurement on its adoption decision: An empirical analysis. International Journal of Production Economics, 158, pp.77-90.

Torvinen, H. and Ulkuniemi, P., 2016. End-user engagement within innovative public procurement practices: A case study on public-private partnership procurement. Industrial Marketing Management, 58, pp.58-68.

Vaidya, K., Sajeev, A.S.M. and Callender, G., 2006. Critical factors that influence e-procurement implementation success in the public sector. Journal of public procurement, 6(1/2), pp.70-99. 
Van Greunen, D., Herselman, M.E. and Van Niekerk, J., 2010. Implementation of regulation-based e-procurement in the Eastern Cape provincial administration. African Journal of Business Management, 4(17), pp.3655-3665.

Van Weele, A.J. and Van Raaij, E.M., 2014. The future of purchasing and supply management research: About relevance and rigor. Journal of Supply Chain Management, 50(1), pp.56-72.

Witjes, S. and Lozano, R., 2016. Towards a more Circular Economy: Proposing a framework linking sustainable public procurement and sustainable business models. Resources, Conservation and Recycling, 112, pp.37-44.

Wu, K.S., Wong, C.C., Chi, S., Tseng, C.H., Huang, P., Huang, D. and Su, T., 2010, June. The improvement of electrical programmable fuse with salicide-block dielectric film in 40nm CMOS Technology. In 2010 IEEE International Interconnect Technology Conference (pp. 1-3). IEEE.

Yang, S., Lu, Y., Gupta, S., Cao, Y. and Zhang, R., 2012. Mobile payment services adoption across time: An empirical study of the effects of behavioral beliefs, social influences, and personal traits. Computers in Human Behavior, 28(1), pp.129-142.

Zins, A. and Weill, L., 2016. The determinants of financial inclusion in Africa. Review of Development Finance, 6(1), pp.46-57. 